\title{
First report of Diplodia gallae associated with branch canker and dieback of Quercus suber in Tunisia
}

\author{
Islem Yangui ${ }^{1,3} \cdot$ Sawssen Hlaiem ${ }^{2,3}$ - Mohamed Lahbib Ben Jamâa ${ }^{3} \cdot$ Chokri Messaoud $^{1}$
}

Received: 27 September 2021 / Accepted: 6 December 2021 / Published online: 13 January 2022

(c) Società Italiana di Patologia Vegetale (S.I.Pa.V.) 2021

Keywords Dieback $\cdot$ Cork oak $\cdot$ Fungal identification $\cdot$ Pathogenicity tests

In March 2017, dieback of cork oak (Quercus suber L.) trees associated with branch cankers were observed in Bellif forest $\left(9^{\circ} 013^{\prime} \mathrm{N} ; 37^{\circ} 04^{\prime} \mathrm{E}\right.$; alt. $\left.276,7 \mathrm{~m}\right)$ in north-western Tunisia. The estimated disease incidence was $75 \%(\mathrm{~N}=40)$. Small pieces of infected branches were surface-disinfected in alcohol (70\%). Each piece was transferred to potato dextrose agar (PDA) and incubated at $25^{\circ} \mathrm{C}$ in the dark. A collection of thirty isolates was obtained. Colonies on PDA showed initially dense white mycelium gradually darkened with age and becoming grey-black after 7 days at $25^{\circ} \mathrm{C}$. Within 10 days, dark pycnidia measuring $350-500 \mu \mathrm{m}$ in diameter appeared on pine needles placed on cultures incubated under light. Conidia were hyaline, oval and aseptate, turned oblong to ellipsoid, rounded with truncate bases and some of them developed one septum, 18 to $27 \times 10$ to $14 \mu \mathrm{m}$ in size. The fungus was initially morphologically identified as Diplodia gallae (Schwein.) Crous, comb. nov. MycoBank MB817673 (Yang et al. 2016). Molecular identification was performed by sequencing the internal transcribed spacer (ITS)-rDNA and a part of the translation elongation factor

Islem Yangui and Sawssen Hlaiem contributed equally to this work

Sawssen Hlaiem

sawssenhlaiem@gmail.com

1 Laboratory of Nanobiotechnology and Valorization of Medicinal Phytoresources. BP , University of Carthage, National Institute for Applied Sciences and Technology (INSAT), 676,8.1080, UR17ES22 Tunis, Cedex, Tunisia

2 Department of Phytiatry, University of Carthage, National Agronomic Institute of Tunisia (INAT), 43 street Charles Nicolle, 1082 Tunis Mahrajene, Tunisia

3 Laboratory of Managment and Valorization of Forest Ressources, Water and Forestry (INRGREF). BP. N, National Institute for Research On Rural Engineering, 1080 Tunis, Tunisia $1-\alpha($ tefl- $\alpha)$ region for two representative isolates (D.g02 and D.g05) (GenBank accession Nos. OK189675, OK189676ITS and OK263146, OK263147-tef1- $\alpha$ ). BLAST searches of the sequences revealed 100\% (MN634019) and 100\% (MN633972) identity, respectively, with reference sequences of D. gallae isolate (IRNBS8). Pathogenicity tests were carried out on cork oak seedlings of 1-year-old using the two isolates according to Linaldeddu et al. (2008). After 20 days, necrotic lesions developed on all seedlings inoculated with D. gallae. Stem lesions measured $4 \pm 0.5 \mathrm{~cm}$. The control seedlings remained healthy. The fungus was successfully reisolated from the infected stems (90\%), thus fulfilling Koch's postulates. To our knowledge, this is the first report of $D$. gallae associated with branch canker on $Q$. suber in Tunisia and worldwide (Farr and Rossman 2021).

\section{Declarations}

Conflict of interest Authors declare that they have no conflict of Interest.

\section{References}

Farr DF, Rossman AY (2021) Fungal Databases. US. National Fungus Collections, ARS, USDA. Retrieved October 12, 2021

Linaldeddu BT, Hasnaoui F, Franceschini A (2008) First report of shoot blight and dieback caused by Diplodia pinea on Pinus pinaster and $P$. radiata trees in Tunisia. Phytopathol Medit 47:258-261

Yang T, Groenewald JZ, Cheewangkoon R, Jami F, Abdollahzadeh J, Lombard L, Crous PW (2016) Families, genera and species of Botryosphaeriales. Fungal Biol. https://doi.org/10.1016/j.funbio. 2016.11.001

Publisher's Note Springer Nature remains neutral with regard to jurisdictional claims in published maps and institutional affiliations. 